\title{
ANALYSIS OF LABOR RISK INDICES IN THE COLOMBIAN PRODUCTIVE SECTOR
}

\section{HENRY MONTAÑA QUINTERO, VICENTE REYES MOZO \& HOLMAN MONTIEL A}

Associates Professors, Universidad Distrital Francisco José de Caldas, Facultad Tecnológica, Bogotá, Colombia

\begin{abstract}
In order to minimize the factors that increase the accident rates in the Colombian industry and with the aim of preserving the integrity of the organizations' collaborators, this paper presents an analysis of the behavior of the accident, disease and mortality rates at work presented by the Ministry of Health and Social Protection between the years 2015 and 2019 ; at the same time, some technologies that can be used for the reduction of the factors that represent risk for the workers are mentioned.

KEYWORDS: Labor Risk, Accident, Disease, Mortality, Technology
\end{abstract}

Received: Jun 08, 2020; Accepted: Jun 28, 2020; Published: Aug 11, 2020; Paper Id.: IJMPERDJUN2020733

\section{INTRODUCTION}

According to the International Labour Organization (ILO), an estimated 2.78 million workers die each year from occupational accidents and diseases, 2.4 million of these deaths are linked to occupational diseases and 374 million workers suffer non-fatal occupational accidents. Likewise, it is estimated that 1000 people die every day in the world due to occupational accidents and 6500 due to occupational diseases [1].

On the other hand, a study conducted on the main global occupational risk factors for 2016 shows that the greatest number of diseases are caused by ergonomic factors, trauma, risk of injury, airborne particles, gases, smoke and noise, and the main burden in terms of deaths is generated by carcinogens [2]. In addition, according to the World Health Organization (WHO) [3], some of the chronic diseases that account for a considerable portion of morbidity are back pain, hearing loss, chronic obstructive pulmonary disease, asthma, trauma, lung cancer, leukemia, and depression.

However, the mortality rates in the world by professional causes are distributed as follows: $65 \%$ in Asia, 11.8\% in Africa, 11.7\% in Europe, 10.9\% in America and 0.6\% in Oceania [1], this represents the segmentation of the population of workers in the world and of dangerous work, also reflecting the levels of economic development.

In Colombia, given the variety of industries, there are various occupational risks inherent in the type of activity carried out. These risks sometimes do not allow the execution of operational activities to be carried out with the necessary safety by the worker. In the construction sector, for example, the handling of heavy machinery, electrical work and work at heights are some of the tasks that demand the greatest care and therefore greater supervision must be provided by business organizations.

At the local level, the work done in the area of worker protection has been more widely accepted in recent years, which is optimal for seeking new alternatives that help improve the working conditions of the internal client. As a result, companies must identify hazards, validate risks [4] and prioritize the implementation of occupational 
health and safety management systems in order to protect the physical integrity of their employees and reduce the accident rate at the workplace.

Workplace accidents can be caused by physical deficiencies in the facilities or by human negligence. More technically, these are determined as immediate or basic causes: those that directly produce accidents are determined as immediate and these are caused by unsafe conditions (generally associated with the installation and handling of tools and equipment in poor condition) [5].

Another factor involved in labor accidents is economic, since both the company and the workers are directly involved in the unforeseen situation, generating intangible costs that mainly represent the affectation, suffering and suffering of the worker, causing psychosocial problems such as stress related to the accident or illness, and tangible costs corresponding to the loss of production [6].

The purpose of this research is to provide an analysis of the behavior of accidents, illness and death at work presented between the years 2015 and 2019 within the industries in Colombia to expose the technological opportunities that aim to reduce the rates presented. These suggestions will help to reduce risks and will allow to look for alternatives that serve to counteract the present affectations reflected within the national industry, with the purpose of helping to create safe environments that have as priority to preserve the integrity of the workers and to increase the enterprise competitiveness.

\section{METHODOLOGY}

In the first instance, a statistical analysis will be conducted that directly provides information on the number of members of the General System of Occupational Risks in business organizations from 2015 to 2019. This analysis will also provide information on the different factors that cause accident rates to be higher in Colombia, such as deaths in the workplace, occupational diseases and professional accidents[7].

On the other hand, the presentation of technology will be made, whose main objective is to describe possible strategies to help national industry generate better management systems in industrial safety and health at work, strengthening the culture of good practices and protection of life [8]. All of this is established to improve the indices that are currently reflected at the national level and to improve them in the future on the eve of being pioneers in the processes of labor protection and process control, evolving drastically in the implementation and management of alternative systems that can solve the shortcomings presented [9].

\section{DEVELOPMENT AND DISCUSSIONS}

\section{Statistical Analysis}

In the statistical analysis, data published by the Ministry of Health and Social Protection are studied. This entity oversees collecting information related to the rates of accident, illness and mortality in the workplace within organizations. For the elaboration of the analysis the behavior of the years 2015 to 2019 is observed with the objective of identifying the main factors that affect the obtained data and in this way to shape some strategies to achieve the internal improvement of the companies and to diminish the indexes of accident rate establishing better environments.

Initially, Table 1 shows the information on the employed population, defined as the persons who were working during the period and the workers affiliated to the General System of Labor Risks for the corresponding year. 
Table 1: Workers Affiliated to the General System of Occupational Risks

\begin{tabular}{|c|c|c|}
\hline Year & Population Occupied & No. Affiliated Workers \\
\hline 2005 & 17.755 .195 & 5.104 .050 \\
\hline 2006 & 16.656 .605 & 5.637 .676 \\
\hline 2007 & 17.456 .744 & 5.945 .653 \\
\hline 2008 & 17.678 .032 & 6.188 .317 \\
\hline 2009 & 19.097 .060 & 6.707 .433 \\
\hline 2010 & 19.549 .661 & 6.828 .126 \\
\hline 2011 & 20.770 .257 & 7.851 .817 \\
\hline 2012 & 21.040 .393 & 8.093 .537 \\
\hline 2013 & 21.583 .721 & 8.434 .862 \\
\hline 2014 & 21.822 .962 & 9.020 .355 \\
\hline 2015 & 22.367 .484 & 9.546 .636 \\
\hline 2016 & 22.461 .004 & 9.620 .228 \\
\hline 2017 & 22.649 .261 & 9.788 .843 \\
\hline 2018 & 22.953 .012 & 9.984 .636 \\
\hline 2019 & 22.760 .730 & 10.528 .465 \\
\hline
\end{tabular}

Source: Author's elaboration - Data taken from the Ministry of Health and Social Protection [7]

According to the data presented in Table 1, the number of employed people for 2019 is 22,760,730 workers and the total number of members of the General System of Labor Risks for the same year is $10,528,465$. This indicates that $46.26 \%$ of the population that works at present is affiliated with labor risks, in contrast to $53.74 \%$ who are not affiliated, which means that labor guarantees are not being provided for employees, representing a high risk for them. However, despite the percentage of non-affiliates, it can be inferred that in the last five years the number of affiliated workers has increased, which indicates that the organizations seek to protect their collaborators through the Labor Risks System.

Other factors to be analyzed are the rates of accidents, diseases and deaths classified as work-related presented by year; for this purpose, first of all, the data obtained for each of the rates is presented as shown in Table 2, where the traceability of the information since 2005 can be observed. It should be noted that the results of the rates for accidents are represented per 100 workers affiliated and those for occupational diseases and deaths per 100,000 affiliates:

Table 2: Rates of Accidents, Diseases and Deaths Classified as Work-Related by Year

\begin{tabular}{|c|c|c|c|}
\hline Year & $\begin{array}{c}\text { Occupational Accident Rate } \\
\mathbf{x ~ 1 0 0}\end{array}$ & $\begin{array}{c}\text { Occupational Disease Rate } \mathbf{x} \\
\mathbf{1 0 0 , 0 0 0}\end{array}$ & $\begin{array}{c}\text { Occupational Death Rate } \mathbf{~} \\
\mathbf{1 0 0 , 0 0 0}\end{array}$ \\
\hline 2005 & 5,16 & 37,4 & 11,50 \\
\hline 2006 & 5,23 & 52,06 & 11,60 \\
\hline 2007 & 5,52 & 67,97 & 12,80 \\
\hline 2008 & 5,83 & 99,3 & 12,01 \\
\hline 2009 & 6,12 & 99,12 & 8,78 \\
\hline 2010 & 6,48 & 137,81 & 7,16 \\
\hline 2011 & 6,96 & 114,39 & 4,73 \\
\hline 2012 & 7,54 & 117,67 & 6,57 \\
\hline 2013 & 6,31 & 92,33 & 8,95 \\
\hline 2014 & 7,61 & 114,86 & 6,03 \\
\hline 2015 & 7,49 & 100,71 & 5,94 \\
\hline 2016 & 6,52 & 105,55 & 6,03 \\
\hline 2017 & 5,91 & 98,61 & 5,79 \\
\hline 2018 & 5,29 & 104,26 & 5,63 \\
\hline 2019 & 5,88 & 82,30 & 4,57 \\
\hline
\end{tabular}

Source: Own elaboration - Data taken from the Ministry of Health and Social Protection 
In the rate of accidents classified as occupational, the result shows that since 2016 there is a decrease in accidents with respect to 2015 as the rate decreased by 0.97 , and in 2017 it decreased by 0.61 and in 2018 contracted by 0.62 these results compared to the previous year, resulting in fewer workers injured at work. On the other hand, despite the decrease achieved in previous years, by 2019 an increase of 0.59 in the accident rate is observed, indicating that for every 100 workers affiliated approximately six suffer occupational accidents.

For the rate of diseases qualified as occupational during the last five years, various fluctuations in its behavior are exposed, in 2016 it shows a growing variation of 4.84 with respect to 2015, in turn, in 2017 there is a decrease of 6.94 with respect to the previous year. However, in 2018 there is again an increase of 5.65 compared to 2017 and by 2019 there is a significant decrease of 21.96, which indicates that the number of diseases in the country has decreased, with 82.30 cases per 100,000 workers.

The data on the rate of deaths classified as labor show that since 2014 it has tended to be stable and subsequently shows a decrease; however, it can be seen that in 2015 it increased by 0.09 with respect to the previous year, by 2016 the rate remained stable and since 2017 there has been a decrease of 0.24 compared to 2016, in turn in 2018 the rate decreased by 0.16 and in 2019 it had a significant drop of 1.06 indicating that for every 100,000 workers affiliated there were approximately five deaths.

In another order of ideas, according to the economic activity, the rates for accidents, diseases and deaths registered in the year 2019 are shown in Figure 1, which illustrates the behavior of labor accidents.

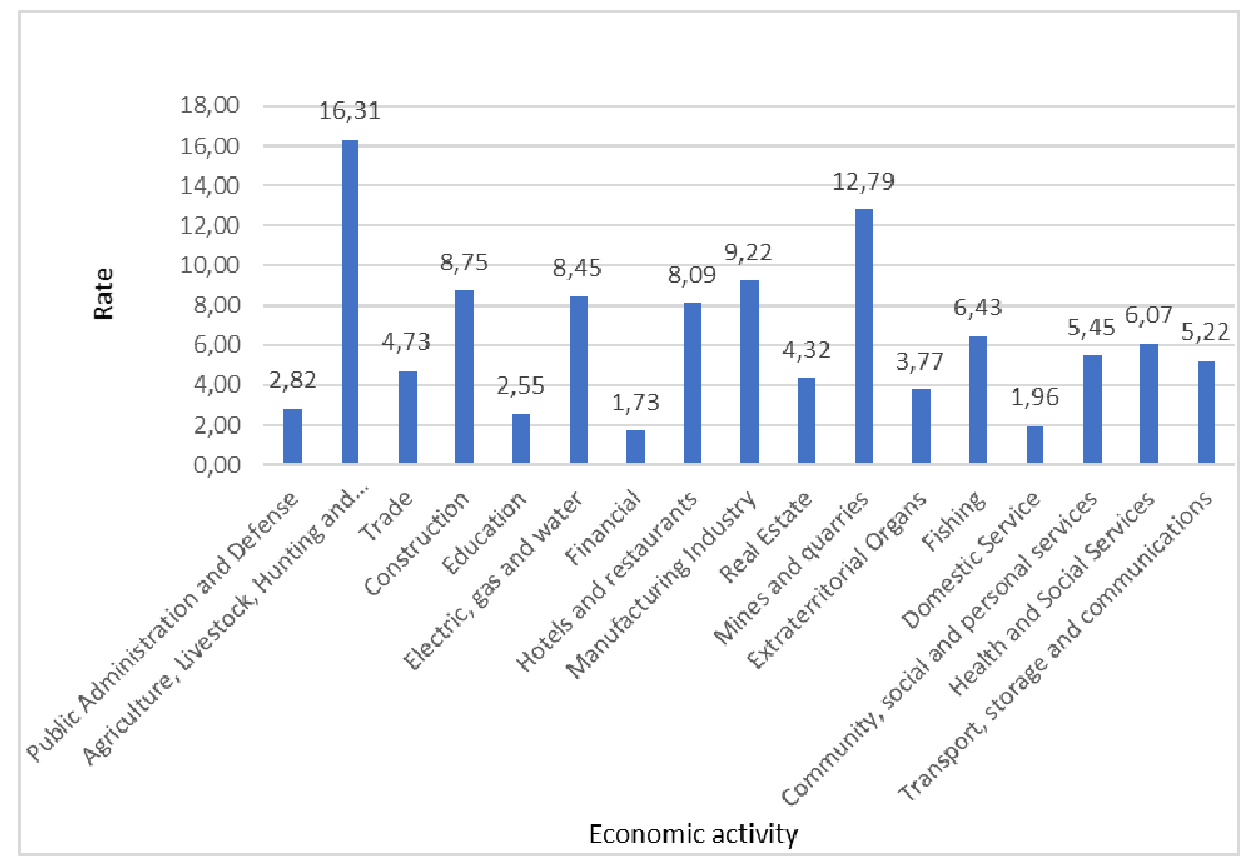

Figure 1: Occupational Accident Rate by Activity x 100 - Year 2019.

Figure 1 shows that the highest number of accidents generated during 2019 was in the agriculture, livestock, hunting and forestry sector, where the rate represents that 16.31 out of every 100 affiliated workers had an accident. Some of the main factors that generate these accidents are: lack of machine maintenance, overturning, collisions and falls from vehicles [10], slips and trips, lifting of heavy objects, animal attacks, entrapment in confined spaces such as manure storage tanks, anaerobic digesters, silos and immersion baths for livestock [11]. 
On the other hand, the rate of occupational diseases is subsequently plotted according to the information captured in relation to the year 2019, identifying the number of diseases classified as occupational acquired in the corresponding economic activity, see Figure 2.

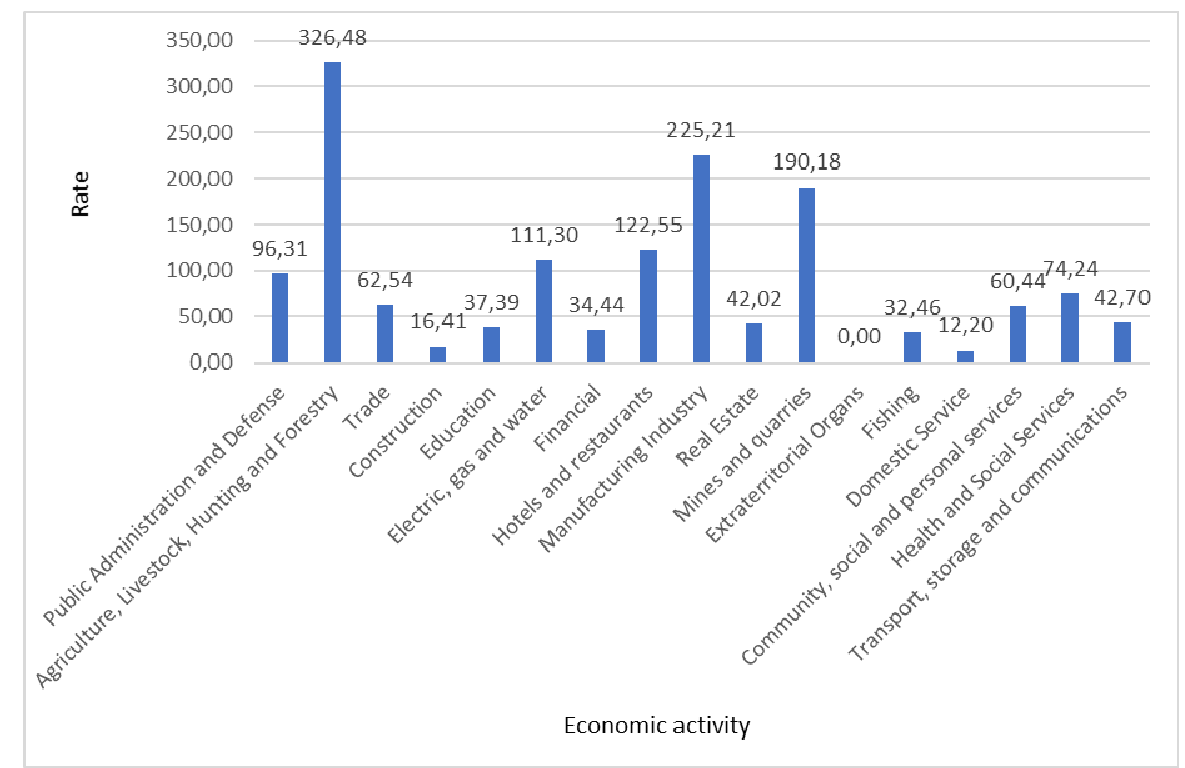

Figure 2: Rate of Occupational Diseases by Activity - Year 2019.

According to Figure 2, the greatest number of acquired occupational diseases is in the agriculture, livestock, hunting and forestry sector, where for every 100,000 workers affiliated with the General System of Occupational Risks there are 326.48 diseases, generating the highest point among all economic activities.

Given the above, the relevant factors involved in the cause of diseases are mainly related to exposure to chemicals such as plant protection products and fertilizers, weather transitions, noise, vibrations, thermal stress, biomechanical hazards and insect bites [12], which generate cancer [13][14], respiratory system problems [15][16],musculoskeletal disorders, Parkinson's disease, hearing loss, low back pain, genetic disorders such as DNA damage, cytogenetic damage [17], and diseases such as malaria, dengue fever and chikungunya [18], among others.

Figure 3 shows that the largest number of deaths in 2019 was in the mining and quarrying sector, where 50.93 deaths occurred for every 100,000 workers affiliated with the General System of Occupational Risks [7], indicating that this is the sector with the highest mortality rate and the one that requires the greatest protection for workers. Consequently, the main causes of death for workers in the mining and quarrying sector include: methane gas explosion [19], dust ignition, motorized transport, falling material, flooding and electrical faults [20]. 


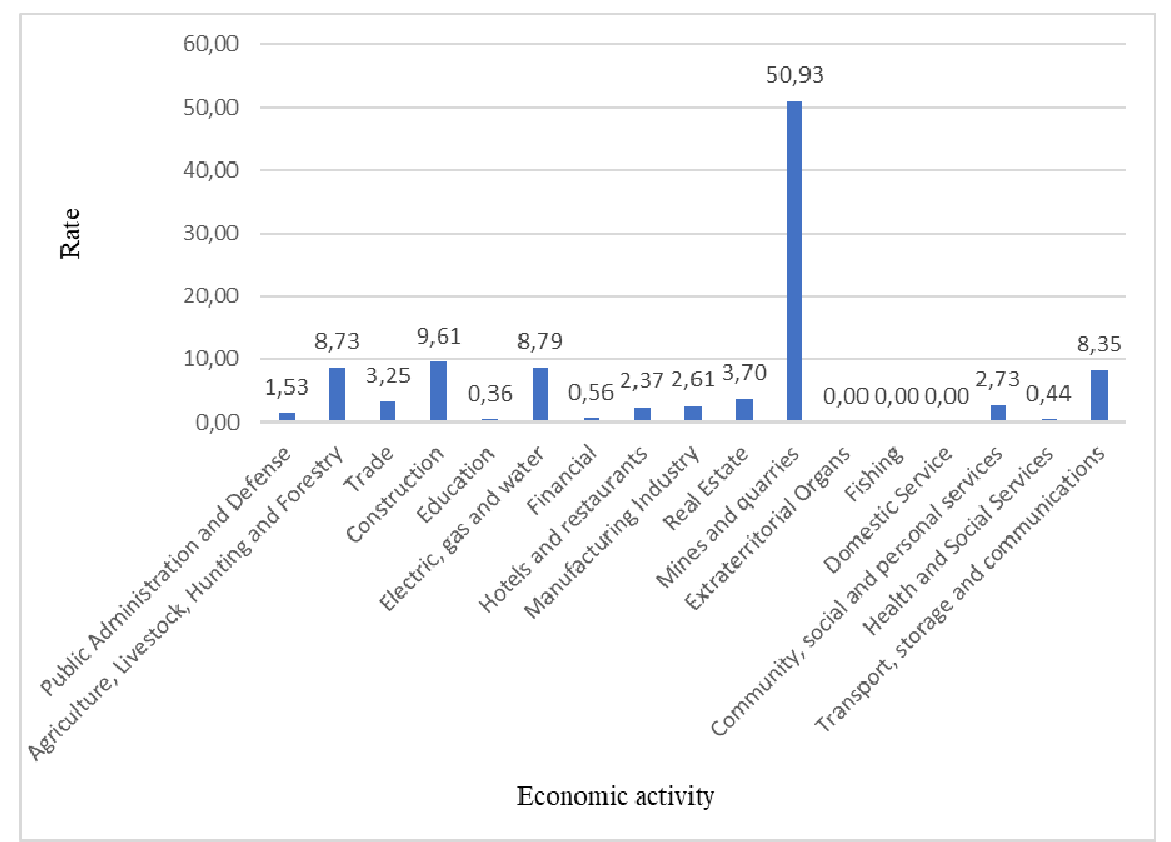

Figure 3: Occupational Death Rate by Activity - Year 2019.

\section{Technological Opportunities for Occupational Risk Protection}

Due to the fact that year after year the patterns of accidents, diseases and deaths at work are constantly changing, technology plays an important role thanks to the progress and impact that it generates in working conditions; improving not only the safety and health of the employee, but also, at the same time, it becomes a fundamental factor that helps to increase productivity in the development of the activities assigned in their workplaces.

One of the main technologies applied within the processes is Artificial Intelligence to avoid actions that represent a risk for workers in activities such as machine maintenance, in turn, the use of Big Data allows the capture, storage and analysis of information to predict situations that trigger accidents and risk conditions [21]. Likewise, currently through the implementation of the Big Data, the movement patterns of the workers are detected, the interrelations between atmospheric factors with the comfort of the worker are observed and the maintenance of factors that represent risk for the collaborators is prevented.

A tool that is a fundamental part of the revolution associated with the current trends linked to Factory 4.0 is the Internet of things. For this case the IoT is used in processes such as air pollution control, identification of particles in industrial environments, gas monitoring, control of variables such as light intensity, pressure, humidity, temperature and noise in working environments. In addition, it could be implemented in the detection of failures in equipment or vehicles, thus ensuring continuous monitoring 24 hours a day, guaranteeing a flow of timely information for decision making associated with any environment in the productive sector.

Another of the technologies implemented is virtual reality, which seeks to simulate industrial environments by computer for the development of activities related to the process, creating a real scenario to generate a sensory experience that allows the construction of a simulated activity (immersion of the worker in the virtual environment) [22].

With the application and adaptation of these advances in the processes carried out by classified organizations in any type of economic activity, many accidents can be prevented. Thanks to the use of these various technological elements, 
data can be captured that allow the analysis of processes and risk indexes when these occur during the execution of an activity by the operator.

\section{CONCLUSIONS}

According to the data analyzed, it can be seen that, in relation to the rate of diseases and mortality qualified as occupational, the behavior of the rates over the last five years is tending to decline; however, the processes of protection for workers must continue to be improved to ensure that these factors continue to fall and reduce the rates even further.

In order to obtain a high number of protected workers, it is necessary that the entire population that is employed or active in the workplace be affiliated with the General System of Occupational Risks to contribute to the protection of their integrity and health.

Through the implementation of various technological tools in the production processes, it contributes to the protection of the workers, since it is possible to follow up the factors involved within the operations allowing to anticipate in real time situations that represent a risk for the collaborators.

\section{REFERENCES}

1. International Labour Organization (ILO), "SAFETY AND HEALTH AT THE HEART OF THE FUTURE OF WORK,Building on 100 years of experience," Geneva, Switzerland, 2019.

2. T. Driscoll, "1372 The 2016 global burden of disease arising from occupational exposures," Occupational and Environmental Medicine, vol. 75, no. Suppl 2. 2018.

3. World Health Organization, "protecting-workers'-health,".2017. [Online]. Available: https://www.who.int/news-room/factsheets/detail/protecting-workers'-health.

4. E. Bedoya, C. Severiche, D. Sierra, and I. Osorio, "Work Accidents in the Construction Sector: The Case of the District of Cartagena de Indias (Colombia)”, Informacióntecnológica, vol. 29, no. 1. pp. 193-200, 2018.

5. A. González, J. Bonilla, M. Quintero, C. Reyes, and A. Chavarro, "Analysis of the causes and consequences of accidents occurring in two constructions projects," Revistaingeniería de construcción,vol. 31. pp. 5-16, 2016.

6. K. Acevedo and M. Yánez, "Costs of Work Accidents: Cartagena-Colombia, 2009-2012," Cienc. Psicol,, vol. 10, no. 1. pp. $31-41,2016$.

7. Ministerio de Salud y Protección Social, "Indicadores de riesgos laborales." [Online]. 2020.Available: https://www.minsalud.gov.co/proteccionsocial/RiesgosLaborales/Paginas/indicadores.aspx.

8. B. Pérez, "Occupational health and safety in business companies," RevistaCiencia y Cuidado, vol. 11, no. 1. pp. 57-67, 2014.

9. M. Riaño, E. Hoyos, and I. Valero, "Progress of an occupational health and safety management system that impacts workplace accidents: Case study of petrochemical companies in Colombia" Ciencia\&trabajo, vol. 18, no. 55, pp. 68-72, 2016.

10. J. Mangado, P. Arnal, A. López, S. Arazuri, and C. Jarén, "Accidentes mortales en el sector agrario en los últimos 15 años," X Congreso Ibérico de Agroingeniería. Huesca, España, 2019.

11. Oficina Internacional del Trabajo, Seguridad y salud en la agricultura. Repertorio de recomendaciones y prácticas, Primera Ed. Ginebra, 2011. 
12. R. Cabello, "Manual de Prevención de Riesgos en Labores de Cosecha y Embalaje de Frutas de Exportación." Santiago, Chile, 2015.

13. G. Andreotti et al., "Glyphosate Use and Cancer Incidence in the Agricultural Health Study," JNCI: Journal of the National Cancer Institute, vol. 110, no. 5. Oxford Academic, pp. 1-9, 01-May-2018.

14. M. Sharma et al., "Factors Associated with the Prevalence of Prostate Cancer in Rural Saskatchewan: The Saskatchewan Rural Health Study,” The Journal of Rural Health, vol. 32, no. 2. Blackwell Publishing Ltd, pp. 125-135, 01-Mar-2016.

15. G. Moncada and E. Moran, "Influencia de enfermedades respiratorias debido al uso de fungicidas en habitantes de la Hacienda Sonnia y Piedad del Recinto Zapote Cantón Urdaneta Provincia de Los Ríos mayo-septiembre 2019.” Babahoyo: UTB-FCS, 2019, Ecuador, 2019.

16. J. Hoppin et al., "Pesticides and atopic and nonatopic asthma among farm women in the agricultural health study," American Journal of Respiratory and Critical Care Medicine, vol. 177, no. 1. American Thoracic Society, pp. 11-18, 01-Jan-2008.

17. T. H. Y. Nguyen, M. Bertin, J. Bodin, N. Fouquet, N. Bonvallot, and Y. Roquelaure, "Multiple Exposures and Coexposures to Occupational Hazards Among Agricultural Workers: A Systematic Review of Observational Studies," Safety and Health at Work, vol. 9, no. 3. Elsevier Science B.V., pp. 239-248, 01-Sep-2018.

18. M. Saxena and M. M. Burke, "Communicable diseases as occupational hazards for agricultural workers: Using experience sampling methods for promoting public health., International Perspectives in Psychology: Research, Practice, Consultation, vol. 9, no. 2. American Psychological Association (APA), pp. 127-130, Apr-2020.

19. L. Méndez, "El trabajo minero: accidente, enfermedad y muerte,” El Cotidiano, no. 169. pp. 71-82, 2011.

20. Mining Technology, "US mining industry accidents and fatalities in 2018 analyzed". 2018. [Online]. Available: https://www.mining-technology.com/mining-safety/us-mining-accidents-fatalities-2018.

21. Murcia Diario, "Tecnología 4.0 para prevenir accidentes laborales en las empresas del metal | Murciadiario. El diario económico de Murcia. Economía, Empresas, Asociaciones, Región de Murcia,” 2019. [Online]. Available: http://murciadiario.com/art/17728/tecnologia-40-para-prevenir-accidentes-laborales-en-las-empresas-del-metal.

22. Fundación Estatal para la Prevención de Riesgos Laborales F.S.P, "Guía sobre tecnologías innovadoras para el cumplimiento de las obligaciones en materia de prevención de riesgos laborales.” Zaragoza, España, 2018. 